\title{
Fronts and Seabird Aggregations in the Southeastern Bering Sea
}

\author{
David Schneider \\ Ecology and Evolutionary Biology, University of California, Irvine, California 92717, USA
}

\begin{abstract}
A number of recent studies suggest that biological activity may be enhanced at fronts, which mark the boundary between water masses. Concurrent bird and physical oceanographic data were collected along a transect that crosses 3 fronts in southeastern Bering Sea. A simple regression-against-distance model was used to describe location and structure of bird aggregations along this transect. Significant bird aggregations coincided with 2 of the 3 fronts, 1 at the shelf break and 1 associated with the $50 \mathrm{~m}$ isobath. Aggregations at the shelf break front were composed of surface foraging birds (fulmars and petrels). Aggregations near the shallow sea front were composed of subsurface foraging birds (murres and shearwaters). The sizes of these aggregations suggest that high rates of carbon flux to upper trophic level consumers may occur in limited areas.
\end{abstract}

Enhanced biological activity has been frequently postulated at fronts (Uda, 1938; Pingree et al., 1974) based on the intensified physical processes at these water mass boundaries (James, 1978; Simpson and Pingree, 1978). Most biological studies have focused on primary production (Pingree et al., 1975; Fournier et al., 1977; Iverson et al., 1979a), and on mechanisms of nutrient regeneration (Floodgate et al., 1981). Increased consumer activity at fronts may result from increased primary production, or from secondary concentrating mechanisms at fronts, in the absence of increased phytoplankton production. Qualitative effects have been reported for several consumer groups (Holligan, 1981), including marine birds (Brown, 1980; Ainley and Jacbos, 1981). For mobile marine consumers such as seabirds, numbers or biomass may not be correlated with feeding activity. For seabirds, feeding (coalescing) and post-feeding (dispersing) aggregations are recognizable by the decrease in density as one moves away from the center of activity (Hoffman et al., 1981). This paper describes the location and structure of pre- and post-foraging seabird aggregations, relative to fronts and chlorophyll maxima encountered along a $534 \mathrm{~km}$ transect across the Bering sea shelf.
Concurrent bird and physical oceanographic data were collected from 31 May to 3 June, 1981 as part of a multidisciplinary investigation of the Processes and Resources of the Bering Sea Shelf (PROBES). CTD (conductivity-temperature-depth) casts were made at $25 \mathrm{~km}$ intervals along a well-studied transect which runs from $54^{\circ} 51^{\prime} \mathrm{N}, 167^{\circ} 52^{\prime} \mathrm{W}$ to $58^{\circ} 29^{\prime} \mathrm{N}, 162^{\circ} 09^{\prime} \mathrm{W}$, or roughly northeast toward Cape Newenham from a point beyond the shelfbreak. The transect lies midway between the Alaska Peninsula and the Pribilof Islands. Chlorophyll ' $a$ ' concentrations were measured fluorometrically in surface hydrocasts at each station. Bird counts were made while underway between stations, from dawn to dusk. Four to 6 ten-minute counts were made per hour. All birds except ship-followers were recorded in a $90^{\circ}$ sector extending $300 \mathrm{~m}$ forward and abeam. Ship location was recorded at the start and end of each count in order to compute the area scanned during each count. Fronts were defined by computing the variance in temperature and salinity between adjacent stations, using ten meter depth intervals to pair measures from adjacent stations. The formula used was:

$$
\Delta U^{2}=(d-1)^{-1} \frac{\mathrm{d}}{\Sigma}\left({ }_{x} U_{i}-{ }_{y} U_{i}\right)^{2}
$$

$U=$ temperature or salinity; $d=$ number of $10-\mathrm{m}$ depth intervals; $i=$ depth in tens of meters; $x$ and $y$ are adjacent stations.

This statistic has a maximum value between stations with high horizontal gradients, i, e. at fronts; it has a low value when adjacent stations have homogeneous temperature or salinity structures. Temporal variation included in this measure was checked by computing the variance between repeated CTD casts at the first two stations on the line.

A simple regression against distance model was used to distinguish aggregations from passing flocks and background variation in counts. Aggregations 

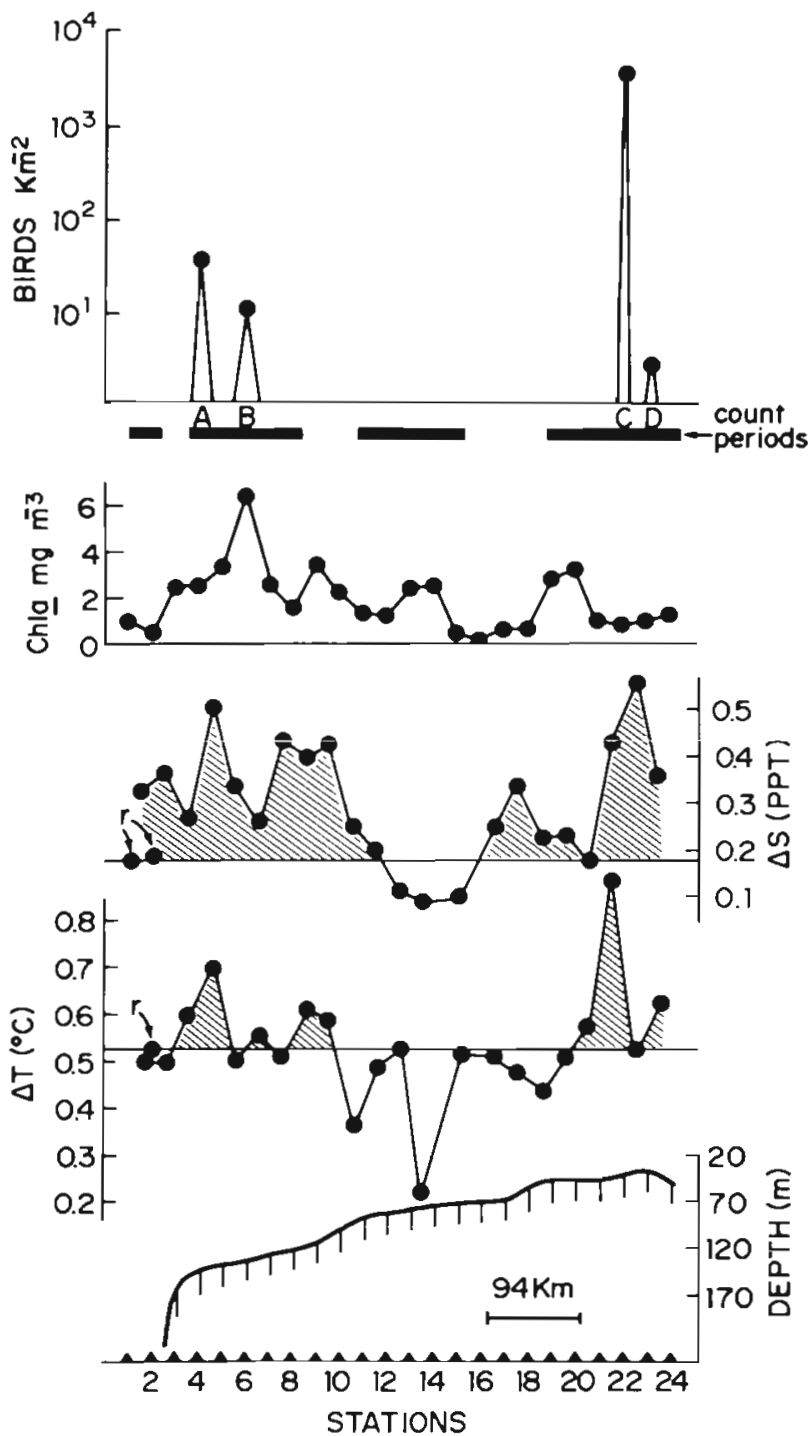

Fig. 1. Water depth, horizontal gradients in temperature $(\Delta T)$ and salinity $(\triangle S)$, and 4 bird aggregations $(A, B, C$, and $D)$ on a cross-shelf transect. Dominant bird species in these 4 aggregations are listed in Table 1. $\mathrm{r}=$ root mean square deviation for replicated CTD casts at one station were measured by identifying each point with a higher bird density than that of the 4 nearest points, and testing for a significant decrease in density with increasing distance from this point. Choosing a peak count to begin analysis required dropping a degree of freedom in testing for significance. The procedure was checked by substituting random numbers for the 90 bird counts made along the study transect. Out of 18 'peaks' in the random data, only one reached significance at $p=.05$; none of the 'peaks' in the random data were significant at $p=.01$. Erroneous rejection of the null hypothesis (Type I error) occurred in 1 out of 18 cases, a value close to the expected error rate of 1 in 20 $(5 \%)$. The procedure gave a measure of variance explained by distance $\left(r^{2}\right)$. The rate of attenuation moving away from the peak count is the slope of the least square regression line.

Fronts were encountered at the expected (Kinder and Coachman, 1978; Coachman and Charnell, 1979; Schumacher et al., 1979) positions along the transect at the shelf break, near the $100 \mathrm{~m}$ isobath, and inside the $50 \mathrm{~m}$ isobath (Fig. 1). Two of these fronts were crossed during daylight hours and both of these fronts showed significant aggregations of birds.

Species composition of the 4 aggregations shown in Fig. 1 are listed in Table 1. The shift from fulmars and petrels on the outer shelf to shearwaters and murres on the inner shelf is consistent with previous demonstrations of cross-shelf differences in species composition in the Bering Sea (Iverson et al., 1979b). The shearwater aggregation at the inner front (Fig. 1) was encountered at the same location $1 \mathrm{~d}$ later, and then again $10 \mathrm{~d}$ later. Large aggregations of shearwaters at the inner front are consistent with previous reports (Hunt et al., 1981) of shearwater flocks near the $50 \mathrm{~m}$ isobath.

Seabird aggregations coincided with chlorophyll maxima on the outer shelf (Stations 4 to 6), but not on the inner shelf (Fig. 1). Chlorophyll a maxima at the surface were encountered at Stations 4 to $6\left(6 \mathrm{mg} \mathrm{m}^{-3}\right)$, Station $9\left(3.5 \mathrm{mg} \mathrm{m}^{-3}\right)$ Station 13 to 14 (2.3 to 2.5 $\left.\mathrm{mg} \mathrm{m} \mathrm{m}^{-3}\right)$, Station $20\left(3.2 \mathrm{mg} \mathrm{m}^{-3}\right)$, and Station $24(3.2$

Table 1. Significant bird aggregations for 31 May to 3 June, 1981

\begin{tabular}{|c|c|c|c|c|}
\hline $\begin{array}{l}\text { Station } \\
\text { number }\end{array}$ & $\begin{array}{l}\text { Patch maximum } \\
\text { (birds } \mathrm{km}^{-2} \text { ) }\end{array}$ & $\begin{array}{l}\text { Attenuation coefficient } \\
\text { (birds } \mathrm{km}^{-2} \mathrm{~km}^{-1} \text { ) }\end{array}$ & $x^{2}(p-$ value $)$ & Dominant species \\
\hline 4 & 37 & -1.7 & $.87 \quad(<.05)$ & $\begin{array}{l}\text { Northern fulmar } \\
\text { (Fulmarus glacialis) }\end{array}$ \\
\hline 6 & 11 & -.57 & $.86 \quad(<.01)$ & $\begin{array}{l}\text { Northern fulmar } \\
\text { Fork-tailed storm petrel } \\
\text { (Oceanodroma furcata) }\end{array}$ \\
\hline 22 & 3600 & -324 & $.77 \quad(<.01)$ & Shearwaters (Puffinus sp.) \\
\hline 23 & 7 & -1.1 & $.95 \quad(<.05)$ & Murres (Uria sp.) \\
\hline
\end{tabular}


$\mathrm{mg} \mathrm{m}^{-3}$ ). Increased phytoplankton concentration at the surface may play a causal role at the outer shelf front, where seabird aggregations were composed of surface foraging species (fulmars and petrels). A direct linkage through zooplankton is likely, since both fulmars and petrels can take zooplankton by pecking at the water surface. Activity at the inner front appears to have been beneath the water surface: there was no chlorophyll maximum at the surface, and seabird aggregations were composed of subsurface foragers (shearwaters and murres).

The results of this analysis from the Bering Sea indicate that fronts do play a role in precipitating bird aggregations at sea. Feeding rates at fronts deserve to be examined in light of the fact that an increase in food aggregation increases the rate at which mobile predators take prey (Ivlev, 1961). Prey aggregation and feeding rates at fronts also deserve examination in light of reported concentrations of toxic compounds at fronts (Sick et al., 1978).

Fronts are mesoscale (10 to $100 \mathrm{~km}$ ) features and birds are large marine organisms several steps away from primary production. An association between birds and fronts is somewhat unexpected, if trophic interactions proceed at ever expanding scales of space, time and size of organism (e. g. Haury et al., 1978). Interaction along expanding scales of space and time is to be expected if diffusive forces in the water limit the rate of encounter between prey and predator. However, the positive responses of highly mobile predators to food abundance would act to foreshorten the scales of interaction. One circumstance that favors such responses is the provision of reliable cues by the environment. An organism that can increase its probability of encounter with its prey by detecting a physical cue, and holding its position relative to some physical feature, achieves a selective advantage over its conspecifics. This response, if found in an entire population of consumers, would tend to reduce the rate at which fixed carbon is dispersed away from its source of production. Foreshortening is also favored if predators can detect prey aggregations at a distance, and move rapidly toward them. Birds hold a considerable advantage in that they move through a medium in which visibility is high and viscosity is low. The fact that bird aggregations do occur at fronts, at relatively small scales, indicates that some foreshortening of the scales of trophic interaction does occur in the sea.

Acknowledgements. This research was sponsored by the NSF under grant DPP 7623340 to PROBES, and grant DPP 7910386 to $G$. Hunt. The author wishes to express his thanks to several PROBES investigators for helpful comments and the use of their data: L. K. Coachman, R. Iverson, and T. Whitledge.

\section{LITERATURE CITED}

Ainley, D. G., Jacobs, S. S. (1981). Seabird affinities for ocean and ice edge boundaries in the Antarctic. Deep Sea Res. 28: $1173-1186$

Brown, R. G. B. (1980). Seabirds as marine animals. In: Burger, J., Olla, B. L., Winn, H. E. (eds.) Behavior of marine animals, Vol. 4. Plenum Press, New York, pp. 1-39

Coachman, L. K., Charnell, R. L. (1979). On lateral water mass interaction: a case study, Bristol Bay, Alaska, J. Phys. Oceanogr. 9: 278-297

Floodgate, G. D., Fogg, G. E., Jones, D. A., Lochte, K., Turley, C. M. (1981). Microbiological and zooplankton activity at a front in Liverpool Bay. Nature, Lond. 290: 133-136

Foumier, R. O., Marra, J., Bohrer, R., Van Det, M. (1977). Plankton dynamics and nutrient enrichment of the Scotian shelf. J. Fish. Res. Bd Can. 34: 1004-1018

Haury, L. R., McGowan, J. A., Wiebe, P. H. (1978). Patterns and processes in the time-space scales of plankton distribution. In: Steele, J. H. (ed.) Pattern in plankton communities. Plenum Press, New York. pp. 277-327

Hoffman, W., Heinemann, D., Wiens, J. A. (1981). The ecology of seabird feeding flocks in Alaska. Auk 98: 437-456

Holligan, P. M. (1981). Biological implications of fronts on the northwest European continental shelf. Phil. Trans. R. Soc. A302: 547-562

Hunt, G. L., Gould, P., Forsell, D., Peterson, H. (1981). Pelagic distribution of marine birds in the eastern Bering Sea. In: Hood, D. W., Calder, J. A. (eds.) The eastern Bering Sea shelf: oceanography and resources, Vol. 2. University of Washington Press, Seattle, pp. 689-717

Iverson, R. L., Whitledge, T. E., Goering, J. J. (1979a). Finestructure of chlorophyll and nitrate in the southeastern Bering Sea shelf break front. Nature, Lond. 281: 664-666

Iverson, R. L., Coachman, L. K., Cooney, R. T., English, T. S., Goering, J. J., Hunt, G. L. Jr., Macauley, M. C., McRoy, C. P., Reeburgh, W. S., Whitledge, T. E. (1979b). Ecological significance of fronts in the southeastern Bering Sea. In: Livingston, R. J. (ed.) Ecological processes in coastal and marine systems. Plenum Press, New York, pp. 437-466

Ivlev, V. S. (1961). Experimental ecology of the feeding of fishes, Yale University Press, New Haven

James, I. D. (1978). A note on the circulation induced by a shallow-sea front. Estuar. coast. mar. Sci. 7: 197-202

Kinder, T. H., Coachman, L. K. (1978). The front overlaying the continental slope of the eastern Bering Sea. J. geophys. Res. 83: 4551-4559

Pingree, R. D., Forster, G. R., Morrison, G. K. (1974). Turbulent convergent tidal fronts. J. mar. biol. Ass. U. K. 54 : 469-479

Pingree, R. D., Pugh, P. R., Holligan, P. M., Forster, G. R. (1975). Summer phytoplankton blooms and red tides along tidal fronts in the approaches to the English Channel. Nature, Lond. 258: 627-677

Schumacher, J. D., Kinder, T. H., Pashinski, D. J., Charnell, R. L. (1979). A structural front over the continental shelf of the eastern Bering Sea. J. Phys. Oceanogr. 9: 79-87

Sick, L. V., Johnson, C. C., Engel, R. (1978). Trace metal enhancement in the biotic and abiotic components of an estuarine tidal front. J. geophys. Res. 83: 4659-4667

Simpson, J. H., Pingree, R. D. (1978). Shallow fronts produced by tidal stirring. In: Bowman, M. J., Esias, W. E. (eds.) Oceanic fronts in coastal processes. Springer, Berlin, pp. $29-42$

Uda, M. (1938). Researches on 'Siome' or current rip in the seas and oceans. Geophys. Mag. 11: 307-372

Accepted for printing on July 28, 1982 